\title{
Planning Dhaka as a Global City: A Critical Discourse
}

\author{
Dr. A K M Abul Kalam*
}

\begin{abstract}
Cities and city regions are practically observed to be the engines of economic growth in the age of globalization. Cities and their regions thus diversely play important roles in national and international contexts. City provides opportunities for economic growth and development and quality life for its population and services to its outside areas, sometimes exceeding the national boundaries. Globalization has, however, created both opportunities and threats for the survival of cities. To become an active partner in the process of globalization, cities with their regional economic strengths require preparing them with their potentials and removing weaknesses. As a capital city, Dhaka has potentials for becoming a global city with its geopolitical location and economic prospects. It has political and administrative advantages in the national context and scope for utilizing the benefits of urban economics, especially agglomerations, concentration of labor and financial institutions, and business services. The physical growth of the city is, however, associated with many-faceted problems which has to be addressed in its planning and development processes in order to bring functional efficiency of a modern city. The city must be developed in a planned manner to benefit from global market and international investment. The research recommends that Dhaka and its city region should overcome the current weaknesses to utilize its full potential to attract businesses and investments in the future. Dhaka's physical development and economic growth management must be considered together in order to becoming a global city playing dynamic role in the global market in future.
\end{abstract}

\section{Introduction}

Despite many criticisms of globalization, countries and their cities have been competing for obtaining benefits from global market since globalization started impacting on the national and regional economies across the globe. The benefits from globalization are many but to gain from global competition, a country requires preparing itself in all possible ways. A loose foot in the process of globalization may adversely harm its economy. As a result, countries and their regions need to prepare themselves with their strengths to compete in the global market. They need to think globally and act locally in order to gain from globalization.

In the recent time, many cities and their regions in the world have spectacularly performed to gain economic benefits from global market. This has been happening particularly since the second half of the 1980s. Since then many cities in the world have successfully made economic gains from global market and contributed greatly in their national development. Many cities in the developing world have also joined this race very successfully. Major cities in the Association of South East Asian Nations (ASEAN) and some cities in South Asia have performed well under globalization. Singapore, Bankok, Manila, Mumbai, Bangalore (the Silicon Valley of India) are good examples of beneficiaries from globalization. Many small cities in the developed world have made good fortune and have been the agents of rapid economic transformation in their regions. These cities have performed dynamic roles in adopting effective policies and strategies in the face of global competition and opportunities.

Dhaka has experienced a noticeable economic growth in the recent period, but as a capital city it has potential to gain more from globalization. To perform at a higher level in the global market, Dhaka as a city has its weaknesses and problems. Though a Master Plan was made for Dhaka City

* Professor, Department of Urban and Regional Planning, Jahangirnagar University, Dhaka, E-mail:kalamabul@hotmail.com 
in the late 1950s and later in the mid 1990s a large area was brought under Dhaka Metropolitan Development Plan (DMDP), there is no denying the fact that the city has largely grown in an unplanned manner. The city and its region lack attractions to get large scale investment from foreign entrepreneurs. However, with appropriate planning interventions, the capital city may overcome its weaknesses substantially, if not fully. This is, where we require employing our attention and sincere efforts to make Dhaka a more efficient city to play a greater role in national and international contexts. This paper aims to explore the opportunities that globalization offer for large cities and their regions in developing countries in terms of economic growth and development. Simultaneously, it examines Dhaka's problems, potentials and future prospects of becoming a global city. In doing so, how a better planned Dhaka city may contribute more in an overall development in the future, has been critically appraised. Methodologically, the research has been based mainly on published literature and documents to understand the role of a mega city in the global market and where Dhaka stands in that pursuit.

\section{Role of Cities in the Age of Globalization}

A global city in its bid has to perform many important activities in both national and international contexts. A city must offer an efficient system of socio-economic development supported by required physical infrastructures and environmental qualities. Political and administrative importance helps better positioning of a city at the national, regional and world stages. A functionally dynamic, aesthetically beautiful and economically efficient city is capable of attracting investments and businesses from national and international sources. National capital of a country can certainly play a major role in this respect. A city plan offering economic opportunities is an important factor to strengthen a city in all dimensions. Financially, a city should be competitive for investment in industrialization, trade and commerce. Cities of global stature require accelerating their economic growth for improving quality of life both in cities and their regions.

Cities have historically maintained political, economic, and social dominance in the national and international stages. Large cities can play key role in influencing and shaping local, regional and national economies. Scott (2001) argues in the context of globalization that the notion of "world city-region' is emerging as political-economic unit with increasing autonomy of action on the national and world stages. Scott $(1998,2001)$ further observes that as globalization proceeds, an extended mosaic of large city-regions is evidently coming into being, and these peculiar agglomerations now increasingly form the spatial foundations for new world system that has been taking shape since the end of the 1970s. In a similar context, MacLEOD (2001) argues that regional economies are resurging as a result of global transformation and the growth of 'informational economies' has almost reached the point of orthodoxy. The key causal influence on regional development in general has led the new regionalists to overlook important influences on the economic dynamics of the real world regions (Lovering, 1999). Increasingly investments, production, goods and services are becoming globalized and mobile and in such restructuring, transportation and Communications have made a remarkable influence on the pattern of global investments and trade. In the process, traditional economic systems that existed before are no longer capable of maintaining the same level of economic and political influence for modern cities. Critics argue that a range of high-profile regional economies and urban metro poles appear to be surging ahead in the race to be leading motors of wealth creation, and cities with dominant images may prosper faster in the age of globalization.

City regions with their internal and external relations present a complex dynamism and a number of extraordinarily perplexing challenges to researchers and policy-makers, as we enter the twenty first century (Scott, 2001). Felbinger and Robey (2001) argue that globalization involves the most fundamental redesign of political and economic arrangements since the industrial revolution. It seems reasonable to conclude that in order to be successful in a global economy, state and local policy must be redesigned to operate in the emerging new environment. Felbinger and Robey 
(2001) further observe that globalization has broken the linkage between business entities and place-based employees and cities can be described by their business enterprises. Even when cities offer as much as they legally can in terms of tax abatements, infrastructure investments, or other amenities, businesses are free to relocate within the region, to another region, or to another country. Cities thus require maintaining their global competitiveness.

MacLEOD (2001) argues that due to dynamic pace of globalization and concomitant rise of the region as a focal point for economic governance, the nation-state is confronting a series of challenges to its erstwhile power and its institutional capabilities, legitimacy and territorial mapping. He argues that functional restructuring is inevitable, where nation-states are no longer perceived to be capable of managing their economies through redistributive policies and strategic placement of public investments. It is possible that institutional restructuring might be conducted through decentralization of governance by devolving the responsibility to regional stakeholders and strategically significant communities in the name of regionalism.

Globalization produces both winners and losers. Ekins and Newby (1998) argue that in an era of globalization, the economic life of local communities tends to become increasingly extended. The ESCAP (2002) views the process of globalization as the growing integration of economies and societies around the world, and recognizes it as a complex process that is variously affecting different regions, countries and areas, and their population. ESCAP (2002) maintains that globalization is an inevitable, technology-driven process that is increasing economic and political relations between people of different countries and areas. Scott (2001) argues that the diminishing capacity of central governments to deal with policy needs of individual regions means that many regions are now faced with the choice of passive subjection to external cross-border pressures, or active institution-building, policy-making, and outreach in an effort to turn globalization as far as possible to their advantage. A capital city with huge population may certainly accrue large scale economic benefits from global market.

Globalization has not just resulted in international components and activities in the economic development policies of state and local governments, but has also forced their transformation in a more entrepreneurial and progressive direction (Clark and Montjoy, 2001). However, the idea that globalization and the rapid economic change are associated is problematic. Kakabadse et. al. (2004) argues that there is strong need to have a global focus in local actions, such as business development strategy of cities may target export markets in other countries. Kanter (1995) observes that globalization forces governments to scale back their expenditure and privatize services, consumers to see the whole planet as their shopping mall and communities to compete with cities worldwide for prominence as international centers that attract the best companies and jobs. Visibly changes are taking place in the technology-based development in industries and businesses. Poloz (2001) asserted that the information technology revolution is creating productivity enhancements in a way not seen since the invention of electricity. Globalization is forcing companies to restructure their systems and make adjustments in their policies and strategies continuously. As a major city, Dhaka can not avoid the global impact and, therefore, should adjust its strategies to face new challenges of globalization.

\section{Economic Opportunities of Cities and Their Regions}

The city regions are conceived as dynamic forces as opposed to earlier notion of natural phenomenon. The influence of globalization is one major reason for this changing view of city regions. There are issues attached with the study of city regions, such as: unpredictable changes as opposed to natural trend, complexities of measuring the changes, equality and vulnerability, political dimension in city governance. The issues, complexities and problems attached to the functioning of cities are important.

Cities as Places of Attractions: Cities generally are concentrations of lot of physical attractions and socio-cultural facilities. Attractive environment of a city naturally attracts tourists and business visitors. This in turn opens up city's economic opportunities to the potential investors. In 
the age of globalization, tourism forms an important economic sector for physically and socially attractive cities. Development of beautiful water fronts, preservation of historical sites, provision of echo-parks, international sport facilities, attractive accommodations and leisure facilities, comfortable transport system, industrial parks, and above all rich community care management system, all are essential part of city design. A beautiful and functionally efficient city can better attract investments for its economic growth.

Cities as Engines of Economic Growth: In the context of global changes in economic order, MacLEOD (2001 quoting Florida, 1995)) argues that 'globalism and regionalism' are becoming part of the same process of economic transformation. Cities are engines of economic growth, and they can exert a huge influence on regional economy. Hall and Pfeiffer (2000) observe that after population growth, the most visible driving forces for urban change are rising productivity through new technology and higher capital per person and its corollary, the rising income. The share of cities in national output, in almost every country, is much higher than their share of the labor force. Cities are concentrations of both physical and human capital (Hall and Pfeiffer). They maintained:

"Cities everywhere are highly and increasingly tied into a system of global competition - even though everywhere, most of their people work for local markets. So ruthlessly efficient is this global division of labor that all cities have to run in order to keep still. As lower-cost locations compete in the production of goods and services, so do cities constantly need to seek new economic niches. Cities like nations need to travel up the learning curve, moving into activities needing higher investment in human capital - above all, advanced services. This is the history of the most successful cases of urban economic development in recent decades, such as Hong Kong and Singapore".

The dynamics of urban life can generate rapid changes in both material and social circumstances. Newman et. al. (1999) argues that cities are shaped by technological, economic and cultural forces. The emerging global city - a city formed primarily by the globalized economy and information technology - will also be subject to these forces. As they argue part of the pressure on global cities is for them to be part of the global sustainability agenda, and sustainability is the simultaneous improvement of the economy and the environment. Transport and information technology are the primary forces shaping cities and that economic and cultural factors can work through the priority on the provision of infrastructure for these technologies or directly impact through affecting where people choose to live or work.

Berg et. al. (2001) argue that Linkages between the business community and the knowledge infrastructure are relatively well developed and certainly contribute to the success and dynamics of economic cluster. Beauregard (2001) maintains that globalization of the past few decades has been a neoliberal ideology that subordinates the national state to global capitalism, discourages extensive welfare provisions, and encourages place competition. This forces cities, regions and localities to be more competitive in order to attract investors and households to raise tax revenues. At the same time, people are threatened by global forces that seem indifferent if not antagonistic to the cultural particularities embedded in specific places. Andersson (2001) argues that cultural policy, tourism, financial services and technology are the bases on which cities compete for investment and image. Swyngedouw et. al. (2003) argues that creative destruction always involves a process of metabolic transformation that takes place in association with others and extends over a certain geographical space. Under globalization, such destruction takes place with the creation of more innovative technologies. For Felbinger and Robey (2001), global cities need to remain competitive through efficient utilization of their physical and socio-economic opportunities and expanded connections and networking.

Regional income inequality effects due to international trade. The expanding orientation of manufacturing industries toward international markets renders national economies more vulnerable to increased competition and financial shocks (Silva \& Leichenko, 2004). The sources 
of comparative advantage according to agglomeration-based theories, include external economies of scale that are associated with the concentration of both population and industry, spillovers of knowledge, and institutional support structures that exist within these agglomerations. Attention to the differential regional effects of trade is a necessary first step toward ensuring that both the benefits and costs of globalization are shared within and across regions. These arguments and observations may well be the case for city regions.

City Regions as Flexible Production Agglomerations: City regions can play an important role in production agglomerations and enjoy benefits of scale economies. They can also attract investments in offering differential and competitive benefit packages for investors and entrepreneurs. For Scott (1992), flexible production agglomerations will not have high chances of long-term success in the new global economy if their production systems are tilted too far in the direction of purely laissez-faire structures of competition. Scott's observations in this context are relevant. The observations are:

1) The transformation of research results into commercializable products is an endemic problem, both for high-technology and low-technology sectors; 2) The creation and upgrading of labor skills is also a major concern in flexible production agglomerations, as is the encouragement of relevant forms of workers socialization; 3) Many firms in modern flexible production agglomerations are unable efficiently to internalize such basic services as accounting, design, payroll preparation, marketing information, and the like; 4) Cooperative interactions between firms in industrial agglomerations can be a significant stimulus to innovation and continual technological upgrading; and 5) Industrial agglomerations, by their nature, are typically located within units of local government that play a crucial role in managing the systemic market failures and externalities endemic to dense concentrations of land uses. Scott (1992) argues that the role of a city involves functions of a local government, such as infrastructure provision and land use planning, but may also extend into more novel forms of activity such as the laying out and operation of science parks, the underwriting of venture capital activities, the organization of worker training programs, and the formation of private-public development corporations. For Scott (2001), flexible production agglomerations in modern capitalism cannot persist in the long run by seeking to evolve in the direction of some idealized vision of laissez-faire competition, rather there is much evidence, both in theory and practice, to suggest that it is precisely those agglomerations that manage to build for themselves a complimentary fabric of institutional and cultural infrastructures that are most viable and dynamic. There is fear that if current trend continues some redistributive regional policy may well be necessary in the future. The issue of development in the context of city region is thus a pertinent question in the politics of uneven development in the era of flexible production and globalization.

Cities Providing Knowledge-Based Economy: Poloz (2001) made two important observations in the current context of business and development. First, the information technology revolution is creating productivity enhancements in a way not seen since the invention of electricity. Second, globalization and internationalization of business is forcing companies to restructure their activities. A recent work by Intelligent Community Forum (2001) argues that cities and communities may arrange such things as broadband infrastructure, knowledge workforce, venture capital, digital democracy and market prowess to maintain competitive edge. For Patridge (2005), access to information and communication technology (ICT) such as the internet, and the ability to use this technology is necessary for members of community if they are to fully participate in economic, political and social life. Dickstein et. al. (1999) emphasizes that public policies and active participation of local institutions and citizens are necessary to attain sustainability in development.

Cities Providing Connectivity and Networking Opportunities: Today, cities are connected for its future economic growth and progress in community life. Niederman (2002) argues that knowledge management should include consideration of both information systems and human 
resource management. Baumard (2002) argues in this context that knowledge generation has become a dependent variable of the mixed mode network structure. For Rooney et. al. (2003), knowledge people are now much better connected with other similarly knowledgeable people so as to give rise to knowledge-based economy and society. There is, however, lack of evidences as to how far this connectivity is achieved across communities and nations. Undoubtedly, however, dynamic cities can only be formed in today's world with knowledge people in professional practices of city planning and development.

\section{Making Dhaka a Planned Modern City}

Dhaka as a capital city has not received due planning attention since the beginning of Bangladesh as an independent country in 1971. Planning and development actions so far have received a little consideration to utilize the potential of the national capital as a centre for multi-faceted development. Over time, the city has grown with a huge population amidst continuous lack of quality services in most aspects of city life, such as transportation and utilities, housing and community facilities, social and recreational amenities, administrative infrastructures, central business district (CBD), industrial facilities and business services, parks and open spaces, and so on.

The national and local leaderships have paid a little attention to utilize the potential of the national capital as a global city. There has been continuous negligence in developing our cities and towns in planned manner. For Dhaka, and also for other urban centers of different scales in Bangladesh, the plans that were made in different times wasted considerable time in the approval and implementation processes. Implementation of plans in most instances had generally been delayed and in some cases in past, not implemented at all. This has been a common phenomenon during the past political regimes of any identity. In such a situation, there has been a sheer negligence in the preparation of detailed plan for the capital city and strategic plan for its region.

The developers and stakeholders are generally known to be utilizing political means and patronization in matters of building permission. Though city's planning and development authorities have sometimes expressed their concerns in respect of planned development of the city, their voices were not paid due attention by the higher authorities and the national government. Besides, RAJUK as a planning and development authority seriously lacks in technical manpower and logistics support. A few town planners employed in RAJUK is simply a drop in the ocean of the capital city's actual requirement. Again, without an appropriate decision making authority, these town planners can do a little for designing the mega city as political and bureaucratic environments are not conducive for them to play a key role. RAJUK has utterly failed to deliver its planning services to the planned development of capital Dhaka.

The civic society is continuously expressing their concerns on different planning and development problems of the city. Over time, problems of the city have been accumulated and reached a point of serious concern. Such concerns are many faceted, and without a permanent solution of these problems, Dhaka may soon fail to function as a capital city. Already, a large section of Dhaka's population is poor whose quality of life is undermined in the planning and development processes, which must be improved to create a better image of the city.

Implementation of plans is a slow and steady process. Considering this, certain policy interventions are immediately necessary to preserve and protect resources of the areas beyond the current land use plan area. Actions are required to determine the future uses of such areas. For example, Dhaka requires large quantity of land for its future development, as roads and utilities, parks and greeneries, industrial and commercial complexes, social and cultural facilities, and many other community purposes. The road provisions should include major utility lines as well, and it is imperative that such provisions are made immediately to bring ease in community life.

At present, the lands that are vacant are mainly low-lying. Some of these lands may require to be earmarked as urban open spaces, parks and greeneries along with major roads and utility lines. 
Major investments on land are required for such purposes, and it is certain that without any major policy intervention and investment, Dhaka cannot grow as an efficient and livable mega city for tomorrow. The sooner the national government, RAJUK, Dhaka City Corporation and other agencies for different city development services, realize the need for some serious interventions backed by planning enforcement, it is better for the future of the city.

Dhaka faces a critical problem in transportation and communication to establish it as a vibrant city supporting economic growth and quality life. The road network and associated infrastructures are very poor in Dhaka. We may need a multi-layer transportation system for some destinations and routes in the city. Before that we need to explore the possibilities for recirculation of the present traffic to examine how much congestion we may reduce and efficiency we may achieve. The existing ring road has not been fully planned and utilized in this respect. There are examples of ring roads in solving city traffic in western cities.

In the provisions of road infrastructures, emphasis must be placed on the creation of more alternative routes to redistribute major traffic flows of the existing roads and ease traffic congestion of different city locations. Moreover, Dhaka being a mega city and capital of the nation, its transportation and traffic problem should not be considered within city limits only, rather it has to be strategically integrated with national transportation system designed for the future. City planning must consider transport network of the city region in the national context. The present government has taken some moves to bring city planning issues into development policy. It may utilize this opportunity to work prudently utilizing the knowledge and experience of the relevant experts, in particular, the professional urban planners and transport engineers.

Dhaka has a lot to do to become a planned modern city. It requires a detailed plan to modernize the city. A continuous monitoring is necessary for the city area following a detailed area plan. The already built up areas require improvement in services and utilities. We must not forget that city has now grown beyond its legal boundaries to include surrounding lower-order municipalities and towns. So planned development is required for capital Dhaka, considering it as a city region, in which a two-tier municipal system may work with specific functional responsibilities. Some services can be integrated and others may function separately. This might be a pragmatic solution for the future management of urban area centering the capital. Besides, it is necessary to improve the existing city infrastructures as much as possible. Some infrastructures may be integrated with surrounding urban authorities.

\section{Concerns for Dhaka Becoming a Global City}

While modernity and modernist town planning in its various forms have come to dominate the world, many countries and cities have not performed well in the hegemonic circumstances of globalization. The changes that are occurring under globalization are directly or indirectly related to technological changes leading to dynamic transformation of landscapes in major cities of the world. As Solomon (2009) argues in this context, the concerns of a global city is about the dogged and occasionally successful struggle of many to work in the conditions of the present to create places that satisfy the deepest longings that people have for the places they live. Solomon maintains that this struggle is by no means the first reform movement directed at architecture and town planning in the last two hundred years of rapid technological change, population growth, and urbanization; but unlike earlier reform movement, this one is directed at particular conditions and threats presented by the dominant economies and technologies at the beginning of twenty-first century. As he argues, in making a global city, it involves the efforts of all sorts of people from farmers, grocers, and cooks to politicians and bureaucrats. The city and regional planners have an important role to play in this ever changing global dynamics. Consequently, this new urbanism is to embrace new ideas about large cities and city regions in the global context, as a reversal of some aspects of orthodox modern architecture, but more particularly of modernist town planning.

There are researches and studies available concerning planning and development of Dhaka city. 
But these works do not suggest on how the capital city Dhaka should perform the role of a global city. They speak, however, much on the nature of problems that the city is facing and different aspects of potentials that the city possesses for growth and development. As Rahman (2008) observes, in the national politics and decision making processes, town planning receives a little significance and priority. The attitude towards democratic decentralization has not favored strengthening of the local governments in Bangladesh, and municipal planning has been over a long time a neglected concern of the society (Kalam, 2002). Dhaka though is the national capital, situation has not been very different than other cities in the country in terms of planned development to ensure quality life and economic growth. In researches, however, a little is seriously focused on how this capital city can be planned for competing in the global market in future. Some highlights on the existing problems and potentials and directions for developing Dhaka in future are made in this paper.

\section{Problems of Dhaka City}

Image Crisis: Dhaka presents itself mostly as an unplanned city with many problems. In terms of urban life, the city is far behind achieving the required qualities. Amidst some planned areas, and picturesque sites and buildings, the city is troubled by many problems to function as an efficient modern city delivering desired services. Its dwellers experience difficulties in most fronts of life, as it lacks an appropriate city plan to offer the desired quality of life.

The City Plan of Dhaka lacks in long-term vision and, therefore, lacks in definite mission to achieve a multi-faceted development required for its population and economic growth. The planning and development initiatives that are undertaken to address the needs of the national capital contribute largely in Gross Domestic Product (GDP) and export earning. Dhaka suffers, however, from unplanned urban development and inadequate public services. An ineffective system of planning and development control results from ineffective urban governance. City's transportation system including traffic management presents a dismal picture and its economic system is not supported by an appropriate physical plan. The mega city requires immediate planning attention in order to modernize its functions and services to play due role in national and international stages.

City Lacking Basic Infrastructure and Community Facilities: A capital city must be physically attractive and functionally efficient. The city has to improve its basic infrastructure including road network, drainage system, environmental services and community facilities. The national dailies have recently published how the city's water bodies including its rivers and canals are being polluted and creating health risks. The Daily Star in its headline news on June 05 (2009) urged the government for strict enforcement of laws to block grabbers of river banks and polluters of the city's environment. This is an indication on the poor status of planning and development control in Dhaka city. Dhaka as a national capital can not afford to lose its competitiveness in the global market and, therefore, must address such planning and development problems for finding solutions.

There are many physical and socio-economic aspects of the city and its functional region that require proper attention from relevant authorities. Above all, the City needs an effective detailed land use plan with acceptable planning standards following rational conceptual framework and planning principles. Dhaka's Master Plan, known as Dhaka Metropolitan Development Plan (DMDP) is yet not complimented with Detailed Area Plan (DAP) for effective implementation of land use plan. Essentially, the forthcoming DAP should address all necessary issues including those have been raised above. To guide land use and control development in Dhaka Metropolitan Region, the DAP now under preparation by RAJUK, must ensure due quality of services for its economy and people.

Only a few major aspects of weaknesses and problems of Dhaka city are discussed in this paper. There are many other problems that are not discussed, but may equally be of critical concern for 
effective solutions. Potentials of the city or the city region primarily lie in the solution of these problems. But to remain competitive in the global standard, it requires performing with a greater efficiency. The city thus requires a better land use plan and a systemic improvement to connect all parts of the city.

\section{Potentials of Dhaka Becoming a Global City}

Dhaka with its many planning and development problems, have so far made a significant contribution in socio-economic development of the country. Cheap labor has been an important factor for the growth of industries, especially factories of ready made garments in and around Dhaka city. As a capital city with its strategic geographical location in the middle of the national territory, it offers a good communication and transportation network with all important places of the country including the sea ports of Chittagong and Mongla. Besides, being the capital city of the nation, it has the favorable factors for encouraging growth and development in the capital region, which includes a much larger area than the City Corporation area comprising several surrounding towns. In fact, the Detailed Area Plan (DAP) of Dhaka Metropolitan Area (DMDP) currently under preparation by RAJUK is much bigger than the area under Dhaka City Corporation (DCC). The Structure Plan of DMDP envisages principles and guidelines for developing Dhaka Metropolitan Region as a viable city region for physical and socio-economic development that ensures quality living, economic growth and development (RAJUK, 1997). The DAP under preparation should focus on the potentials of Dhaka to grow as a global city attracting businesses and investments. As a mega city, it should focus strongly on tourism development. The planning principles and standards require guiding the city in that direction.

Dhaka's economy: The capital city and its region offer the largest employment in industries, commerce and services, typical for a Capital City. It enjoys the highest concentration of labor, financial institutions and business services. The city also enjoys a concentration of infrastructures in administration, health, education, and professional services. The market sector of Dhaka is, however, not yet well-developed and products other than a few exportable items including readymade garments, are consumed mainly locally. The city has not yet tapped the benefits of high-tech industries, which it should consider in its main economic agenda.

The dynamic growth of financial and service sector is a clear indication that the city region of Dhaka has potential to grow as a global city transacting its products and services around the world. Dhaka's city development and economic growth management plans, therefore, should focus on exploiting its potential in global market. The knowledge-based business services have potential for growth as the city houses a large number of universities producing technical and business graduates. The plans require meeting the criteria of attracting investments from both domestic and international sources. A global city must also be capable of making large investment in tourism development for attracting domestic and international tourists. Not much attention has so far been paid in the city planning of Dhaka city to exploit its tourism potential.

This research is not aimed to prepare an exhaustive list of potentials of Dhaka city or its region, but to highlight some major areas of potentials in order to illuminate the ideas citing some cases that Dhaka's capital region may exploit in great deal in future. Future moves on development of the city should, therefore, consider its economic potentials, while actions for physical development of the city or its region are undertaken for improvement.

\section{Future of Dhaka as a Global City}

Dhaka could be potential a beneficiary of the on-going process of globalization and a base for export earning from industrial products including ready-made garments. The potential of Dhaka's future growth lies in physical and strategic planning of the city and city region. The excellent geographic position of the city in the middle of the country with transport and communication links to most cities and towns, and other important places of the country make Dhaka as the most 
advantageous city. The past industrial experience, administrative importance and cultural heritage testify the significance of its excellent location advantage. Having said so, its is also true that the faster growth of Dhaka city than other cities of the country has created a major problem for Dhaka city region, because of inadequate development of infrastructure, especially the transportation network necessary for a fast growing region in a national and global contexts. The Strategic Transport Plan (STP) makes some suggestions on how to improve the transportation problems of the capital city (GOB, 2004). Further research is necessary as to how the city's transport system can be made efficient and modernized.

Dhaka has loosely followed a strategic plan under DMDP for promoting planned land uses and controlling growth of the city. It requires a strategic plan with serious considerations for competing in the global market as a dynamic player. It should set its own pathway for attracting investments in new businesses and expanding the existing ones. Along with the economic growth and development, Dhaka should aspire for enlarging its economic base for increasing population. The objective of this strategy should be to achieve higher economic growth through increased industrial and commercial activities, and strengthening of real estate and housing, development of transport network for city region connecting major centers of importance, and provision of utilities and community services.

Dhaka's desire for becoming a stronghold in industrial agglomerations and commercial concentrations may receive a positive response by the international investors, if the city could adopt and implement a strategic plan suitable for such actions. Through such actions, Dhaka's clients and customers across national and international boundaries will benefit from its global pursuits. Its continued efforts should be directed to provide opportunities for all who are willing to contribute to Dhaka's journey towards a prosperous economic future. The success of the plan has to be evaluated periodically to see the progress. The city needs an effective development plan to achieve success in economic growth and development. The city should create an image of a modern livable city, before it becomes a global city attractive to international entrepreneurs, investors, business visitors and tourists.

\section{Planning Dhaka as a Global City}

The discussions in the paper, has provided some useful ideas and information as to how a global city should function in a period of globalization. Dhaka to become a globally competitive city, it requires to be planned and developed to perform as a dynamic city. In a recent study on cluster economic development in Dhaka Capital Region, conducted by Asian Development Bank (ADB) found Dhaka's competitiveness is the highest in the country, but is only marginally comparable internationally (ADB, 2009). As per the findings of the study, no other cities but Dhaka only has potential for clustered economic growth and development in the country. Dhaka's present state of urban and spatial development has limitations in both physical and socio-economic development. The study by ADB (2009) argues that capacity building of the local government is necessary to address the need for development of urban areas in a sustainable manner. Local stakeholders should be involved in the process of planning. The planning should be undertaken at various levels, from local to national, and again the local plans should have a hierarchy such as structure plan, area plan and local action plan and so on.

While the need for urban and spatial planning is paramount in the country, the progress in this respect is limited by the absence of effective policies and strategies. The national policies should strongly support for planned urban and spatial development in local and regional contexts. A truly decentralized approach is necessary to strengthen urban local governments in the country, which will help planned urban and spatial development. Targets in sustainable urban development can not be achieved without effective urban governance. The city of Dhaka may perform better along with other cities and towns in the country. 


\section{Conclusion}

Dhaka with its huge population has the potential to be a major global city and should exercise its potential to exploit the global market. With its much potential, especially the favorable factors of production, Dhaka can easily be a global player earning a huge foreign exchange for the nation. To support its mission to become a global city, the authorities at the national, regional and local levels must address Dhaka's planning needs for achieving quality development in and around the city. In the age of globalization, a capital city should utilize the full potential from global market. As capital city of the world's eighth largest country, Dhaka must ensure planned development in both physical and socio-economic terms to be attractive to its own people and visitors and investors from outside. Professionals in the field of city planning have a lot to do in respect of Dhaka's planned development. It is expected that this paper will generate interests among policy makers, planners and other relevant professionals and agencies about the planned development of Dhaka City to raise its standard up to an internationally acceptable level.

\section{References}

Andersson, H. 2001. New spaces of urban transformation: conflicting 'growth areas' in the development of finnish cities. In Change and Stability in Urban Europe: Form, Quality and Governance. Andersson, H., Jorgensen, G., Joye, D. and Ostendorf, W. (eds). 262pp. Burlington, USA: Ashgate

Asian Development Bank (ADB), 2009. City Cluster Economic Development: Dhaka Capital Region, Bangladesh, Draft Summary Report. Dhaka: Asian Development Bank.

Baumard, P. 2002. The sustainability of imaginary organizations: balancing knowledge and trust. In Managing Imaginary Organizations: A New Perspectives on Business B. Hedberg, P. Baumard and A. Yakhlef (eds). Boston, USA: Pergamon.

Berg, L.V.D., Braun, E. and Windeu, W.V. 2001. Growth Clusters in European Cities: A Comparative Analysis of Cluster Dynamics in the Cities of Amsterdam, Eindhoven, Helsinki, Leipzig, Lyons, Manchester, Munich, Rotterdam and Vienna. 272pp. Aldershot: Ashgate.

Clark, C. and Montjoy, R.S. 2001. Globalization's impact on state-local economic development policy. Policy Studies Review 18 (3).

Clark, C., Green, J. and Grenell, K. 2001. Local regimes: does globalization challenge the "growth machine"? Policy Studies Review 18 (3), 49-61

Dickstein, C., Branscomb, D., Piotti, J. and Sheehan, E. 1999. Crafting sustainable development: a study of Maine's Coastal Enterprises, Inc. Making Waves 10 (2).

EASCAP, 2002. Sustainable Social Development in a Period of Rapid Globalization: Challenges, Opportunities and Policy Options. New York: United Nations.

Ekins, P. and Newby Les. 1998. Sustainable wealth creation at the local level in an age of globalization. Regional Studies 32 (9).

EASCAP, 2002. Sustainable Social Development in a Period of Rapid Globalization: Challenges, Opportunities and Policy Options. New York: United Nations.

Felbinger, C. L., and J. E. Robey. 2001. Globalization's impact on state and local Policy: the rise of regional cluster-based economic development strategies. Policy Studies Review, 18 (3).

Florida, R. 1995. Toward the learning region. Futures, 27.

Government of Bangladesh (GOB), 2004. The Strategic Transport Plan for Dhaka.

Hall, P. and Pfeiffer, U. 2000. Urban Future 21: A Global Agenda for Twenty-First Century Cities. New York: E \& FN Spon, Taylor \& Francis Group.

Intelligent Community Forum, 2001. Benchmarking the Intelligent Community, A project of World Teleport Association, New York. http://www.intelligentcommunity.org

Kalam, A. K. M. A. 2002. Community participation in municipal planning and development in developing countries. The Journal of Local Government, 31(2). Dhaka: National Institute of Local Government. 
Kakabadse, A., Bank, J. and Vinicombe, S. 2004. Working in Organisations (Second Edition). Aldershot: Gower.

Kanter, R.M. 1995. World Class: Thriving Locally in the Global Economy. New York: Simon \& Schuster.

Keating, M. 1997. The invention of regions: political restructuring and territorial government in western Europe. Government and Policy, 15.

Keating, M. 1998. The new regionalism in western Europe: territorial restructuring and political change. Cheltenham: Edward Elgar.

Lambi, L., Arias, E. and Freire, G. 1999. Grounding globalization theory: local responses to global processes in the light of the global-local links debate in sociology. In Local Responses to Global Integration C. Kasimis and A.G. Papadopoulos (eds). Aldershot: Ashgate.

Lovering, J. 1999. Theory led by policy: the inadequacies of new regionalism. International Journal of Urban and Regional Research, 23.

MacLEOD, G. 2001. New regionalism reconsidered: globalization and the remaking of political economic space. International Journal of Urban and Regional Research, 25 (4).

Newman, P. Kenworthy, J. and Laube, F. 1999. The global city and sustainability - perspectives from Australian cities and a survey of 37 global cities. In East West Perspectives on $21^{\text {st }}$ Century Urban Development: Sustainable Eastern and Wester Cities in the New Millenium, J. Brotchie, P. Newton and J. Dickey (eds). Sydney: Ashgate.

Niederman, F. 2002. Global information systems and human resource management. In Global Perspective of Information Technology Management F.B. Tan (ed). London, U.K. : IRM press.

Patridge, H. 2005. Establishing the Human Dimension of the Digital Divide. In Information Security and Ethics M. Quigley (ed). London, U.K.: IRM Press.

Poloz, S.S. 2001. Technology \& globalization: twin challenges for Canada. The Economic and Technology Development Journal of Canada.

Rahman, G. 2008. Town Planning and the Political Culture of Planning in Bangladesh. Dhaka: A.H. Development Publishing House.

RAJUK, 1997. Dhaka Metropolitan Development Plan (DMDP) - Volume I: Structure Plan. Dhaka: RAJUK.

Rooney, D., Hearn, G. Mandeville, T. and Joseph, R. 2003. Public Policy in Knowledge-Based Economies: Foundations and Frameworks. 181pp.Cheltenham: Edward Elgar.

Scott, A.J. 1998. Regions and the World Economy: The Coming Shape of Global Production, Competition, and Political Order. Oxford: Oxford University Press.

Scott, A.J. 2001. Globalizations and the rise of city-regions. European Planning Studies, 9 (7).

Singleton, R.A., Straits, B.C. and Straits, M.M. 1993. Approaches to Social Research (Second Edition). New York: Oxford University Press.

Solomon, D. 2009. Global City Blues. Washington: Island Press.

Swyngedouw, E., Moulaert, F. and Rodriguez, A. 2003. The world in grain of sand: large-scale urban development projects and the dynamics of 'glocal' transformations. In The Globalized City: Economic Restructuring and Social Polarization in European Cities. Moulaert, F., Rodriguez, A. and Swyngedouw, E. (eds). Oxford: Oxford University Press.

The Daily Star, 2009. Sincerity the Answer - Headline News on grabbed riverbanks, June 05.

UNESCO, 2000. Socially Sustainable Cities: Principles and Practices. Bailly, A.S., Brun, P. Lawrence, R.J. and Rey, M.C. (eds). Geneva: Economica.

Wilhelm, A.G. 2004. Digital Nation: Towards an Inclusive Information Society. Massachusetts: The MIT Press. 